\title{
AS TARIFAS NAS CONCESSÕES DE SERVIÇOS DE UTILIDADE PÚBLICA
}

TRANCTSEO BUAXINSXI

Técnico de Orçamento no D.A.S.P.

SUMARIO : Preponderância da questão tatifária nos serviços públicos concedidos. Situação da questão tarifátia no Brasil. Sinopse histórica do conceito avaliativo para a fixação de tarifas nos Estados Unidos. $O$ critério do custo histórico e do custo de reprodução no Brasil. $O$ art. 147 da Constituição de novembro. As "holding companies" ou emprêsas vinculadas. Dificuldades da avaliação no Brasil em caso de emprêsa vinculada. Tarifas como fator de ordem pública. Conclusóes.

A questão tarifária assume tamanha importância nos serviços de utilidade pública, dados seus múltiplos aspectos econômicos e administrativos, que a inexistência de um órgão específico destinado à regulamentação das tarifas redundaria, sem dúvida, em sérios prejuízos às coletividades.

8 VITtore VItali, Delle successioni legitime e testamentarie, Torino, 1923, vol. I, pars. 21 e 22 . 
Esse o motivo primordial de se colocar o problema da fixação de tarifas justas e razoáveis como finalidade precípua da regulamentação das indústria produtoras de utilidades públicas, sem o que impossível seria obter-se serviço adequado.

Cabe, porém, uma pergunta : é fácil adotar-se um critério avaliativo na fixação das tarifas?

A questão, devido a complexidade de que se reveste, tem suscitado as mais vivas controvérsias entre economistas, administrativistas, juizes, legisladores e técnicos, tornando abundante a bibliografia e variadas as teorias.

Em face do surto de determinados ramos da indústria privada, caracterizadas pela produção de serviços de utilidade pública, como os de transporte, eletricidade, gás, abastecimento de água e telefone, etc., o Estado se viu na contingência de limitar a atividade particular nesse setor da, economia, controlando o lucro dos empresários, através da regulamentação das tarifas. Efetivamente, essas indústrias, pela sua natureza pública, não mais podiam permanecer entregues ao livre alvedrio de seus agentes, acarretando, pois, a interferência do Estado, como fôrça disciplinàdora dos interêsses entrechocantes. Para isso, porém, foi necessário que a legislação permitisse semelhante contrôle sôbre aquelas utilidades. Eis a razão de, segundo veremos, sobretudo nos Estados Unidos, a tarefa de fixação de tarifas caber no início ao poder legislativo.

Após lutas sucessivas, em que os interêsses do Estado, dos empresárioo e dos consumidores se permesivam, êsse grande país da América do Norte conseguiu criar órgãos técnicos destinados ao contrôle dos serviçós de utilidade pública, as comissões, cujos resultados têm sido benéficos.

Há, também, no Brasil, órgão técnico destinado à fixação das tarifas, ou são elas apenas fixadas no próprio instrumento da concessão de serviços páblicos?

Situação da questão tarifária no Brasil - Em vista da promulgação do decreto $n .^{\circ} 23.501$, de 27 de novembro đe 1933, que aboliu a cláusula ouro, decorrente da necessidade de o Govêrno Provisório rever o contrato celebrado entre a União e a "Société Anonyme du Gas do Rio de Janeiro", todos os contratos de concessão em que havia aquela condição passaram a não ter tarifa: Pela primeira vez nos defrontamos com um grave problema de tarificação. $O$ projeto da Constituição de 1934 , em seu art. $80, n^{\circ} 5$, dava ao Conselho Nacional a atribuição de fixar tarifas. Todavia, já que êsse órgão não exercia funções de ordem técnica, difícil the seria resolver satisfatòriamente a questão.

Fazia-se mistér, pois, a criação de um órgão especializado, em que à administração geral fôsse vedado interferir, pela carência de conhecimentos técnicos. Era preciso que se instituísse um órfão autarquizado.

Isso levou a que o Prof. Francisco Campos sugerisse mais tarde a criação de comissões no Brasil, regulamentadoras de nossos serviços de utilidade pública, tendo por finalidade precípua a fixação de tarifas. Eis sua opinião:

"Em suma, o processo que me parece apropriado a resolver o impasse que se originou, para vários serviços públicos concedidos, da abolição da cláusula curo, é o da fixação de tarifas mediante comissões, investidas de função judicial quanto aos fatos, à sua investigação e à apreciação dos mesmos como elementou de base ou como índice para a fixação das tarifas". 1

Por essa ocasião, o Prof... Francisco Campos, então Consultor-Geral da República, propôs ao Chefe do Govêrno fôsse constituída uma comissão encarre-

1 Francisco Campos, Direito Administrativo, Imprensa Nacional, Rio de Janeiro, pág. 146, 1943. 
gada de elaborar um anteprojeto de decreto em que o assunto ficasse definitivamente regulado.

Essa comissão especial foi posteriormente organizada, a fim de elaborar - anteprojeto da Lei Orgânica Federal, regulamentadora, do art. 147 da Constituição de novembro.

Entretanto, por motivos de ordem vária, nada se resolveu até agora, porque não-foi-promulgada-a lei federal a que se refere aquêle artigo da Constituição, se bem que muitos fôssem os trabalhos apresentados nesso sentido, dignos de exame.

Quais as consequências oriundas da situação em que até hoje nos defrontamos?

Nos centratos de concessão de serviços públicos, as tarifas são fixadas por um longo períoda, e contrôle do Estado cinge-se apenas à fase pré-contratual.

Fixados os preços por um longo período, a companhia concessionária leva em conta, sem dúvida, uma série de fatores que sobremodo a beneficiam, dos quais os mais importante são os riscos imprevistos. Os preços, pois, fixados nos contratos pelas emprêsers, sòmente podem ser elevados, acobertando-a de quaisquer casos fortuitos que possam aumentar o valor do material de que se equipam para fornecer as utilidades públicas. Isso faz com que todo ônus recaia sóbre os usuários do serviço público. Ésses pagam, assim, além do valor dos serviços produzidos, o seguro contra o rișco da majoração de preços do material pertencente aos empresários. Eis como a ausência de um aparelho regulamentador das tarifas pode redundar na fixação das mesmas em detrimento dos usuários.

E necessário, portanto, criar um órgão adequado, que torne as tarifas flexíveis, adaptando-as a cada caso particular, a fim de que a comunidade possa usufruir, mediante módico pagamento, das utilidades a ela fornecidas

De mais a mais, a regulamentação puramente contratual, que de forma nenhuma se considera verdadeira regulamentacão, faz com que o concessio nário não seja obrigado a adquirir novas instalaçōes, exigíveis pelas transformações técnicas e econômicas, perdendo sua função de prestador de serviço público, para tornar-se mero instrumento de lucro.

$O$ art. 147 da Constituição de novembro nos ministra os elementos necessários à regulamentação das tarifas, cujo primeiro pesso seria a elaboração da lei fecteral, propore do critéria mais certo para o cálculo das tarifas, a serem fixadas por entidade técnica.

Onde podemos buscar orientação segura para a adoção de um critério justo e razoável ?

Cuido que a melhor maneira será valermo-nos da experiência histórica dos Estados Unidos, elidir as falhas ali verificadas e examinar o critério atualmente adotado pelas comissões naquele país relativamente ao problema. Feito isso, desde logo notaremos, antes do mais, a necessidade inadiável de também criarmos órgãos especializados na fixação das tarifas.

Vejamos, pois, o desenvolvimento histórico da base de avaliação naquele país da América do Norte.

Sinopse histórica do conceito de analiação para fixacão de tarifas nos Estados Unidos - O curso histórico do critério de avaliação para fixação de tarifas nos Estados Unidos pode resumir-se nas seguintes fases : a) anterior so caso Smyth $\nabla$. Ames; b) do caso Smyth v. Ames à guerra de 1914-18; c) da guerra de 1914-18 aos nossos dias.

Antes de deflagrar a Guerra Civil, não havia grande empenho na regu lamentação dos serviços de utilidade pública, uma vez que alguns serviços astavam ainda em sua fase inicial, e outros, como o de telefone, e fôrça e luz, nem ainda descobertos haviam sido. 
Após a Guerra Civil, começou o conhecido movimento da marcha para o oeste. Estradas de ferro se prolongam para essa direção, onde a agricultura já floresce com exuberância. $O$ progresso era crescente. Os fretes exorbitantes, todavia, bem como os depósitos pagos para armazenagem de mercadorias, provocaram a revolta dos agricultores contra as companhias ferroviárias. Pela primeira vez, promulgam-se leis para reduzir os fretes e para diminuir os depósitos pagos para armazenagem de mercadorias: $O$ legislativo fixa as tarifas até 1876. Até essa data, o judiciário não se opõe à orientação do legislativo em matéria de contrôle administrativo das tarifas. Respeita-lhe o poder de polícia. Depois, porém, começa a vacilar nas suas decisōes. Em 1885, a Côrte Suprema decide que o legislativo não tinha podere ilimitados para fixar as tarifas. Em 1887, já o judiciário cogita da anulação da fixação de tarifas pelo legislativo. A Côrte Suprema estabelece, no caso Dow v. Beidelman, que não possuía provas de quanto custaram as ações, além de suscitar outras dúvidas quanto à estrutura financeira das companhias. Em 1890, o judiciário irroga-se o direito de revista das decisões conclusivas e finais das comissões, a quem o poder legislativo conferira soma considerável de poderes. Em 1892, o judiciário amplia seu poder, atribuindo-se a revisão das tarifas fixadas pelas comissões e pelo legislativo.

Durante todo êsse período que assinalamos, prepondera o critério do custo do reproduçăa. Convém frisar, entretanto, que, naquela época, dado o baixo preço das mercadorias, o custo de reprodução era menor que o custo real.

O segundo período inicia-se em $1898 \mathrm{com}$ a decisão no célebre caso Smyth $\nabla$. Ames, a qual estabelece como base de fixação de tarifas o justo valor, $\theta$ se prolonga sté o caso de Des Moines, ocorrido em 1915.

A propósito do caso Smyth v. Ames, há inúmeras controvérsias. Uns dizem que por justo valor entendeu a Côrte Suprema o custo real, outron dizem que o cussto de reprodução. Basta isso para demonstrar a confusão Existente sôbre o caso.

Diz, porém, John Bauer, a maior autoridade norte-americana no assunto, que o caso Smyth v. Ames não fixou um critério geral, deixando a determinação da fixação de tarifas sujeita às circunstâncias de cada caso particular, se bem que pela primeira vez se falasse em justo valor como critério de avaliação, indo, portanto, a decisão, de encontro ao interêsse público. Acresce, ainda, que, ao tempo, o custo de reprodugăo era menor que o custo real.

Do período que se prolonga do caso Smyth v. Ames até o caso Des Moines, em 1915, predomina como base de avaliação o custo de reproduçāo. Releva ponderar, porém, que, nesse periodo, ao contrário do anterior, houve grande inajoração no preço das mercadorias.

Todo êsse periodo pode sintetizar-se em três fases : a) a Côrte Suprema adere à doutrina controversa do valor atual, e alega que todos os pontos enumerados no caso Smyth v. Ames devem ser levados em conta, como elementos de prova, e não como constituindo parte integrante do valor da propriedade; b) tôdas as decisões reconhecem, mais ou menos, que o valor atual não pode ser identificado com o valor dependente das tarifas e do poder de lucro das emprêsas; c) há tendência clara em aceitar o custo de reprodução, como fator dominante na determinação da base de tarifas. Esboça-se, contudo, movimento no sentido de não se seguir a Côrte Suprema, a não ser quando os acórdãos por ela proferidos resultassem em justiça para o público.

No período que medeia entre o caso Smyth v. Ames e o de Des Moines, observa-se a criação de várias comissōes estaduais, às quais o poder legislativo outorga poderes para fixação de tarifas. Antes do caso Smyth v. Ames, esta incumbência cabia ao legislativo, que, por seu turno, se subordinava ao contrôle do poder judiciário. 
Em 1907, foram criadas a New York Public Service Commission e a Wisconsin Railroad Commission, com atribuições para fixar tarifas razoáveis. Em outros Estados, também, criaram-se comissóes. Assim, já durante a primeira Grande Guerra a competência do legislativo nessa matéria é substituída pela das comissóes, reguladas por estatutos.

Desde o início, as comissốes se caracterizaram em tomar por base, na fixação de tarifas, a avaliação inicial das propriedades, abolindo dúvidas de custo, $\theta$ confiado, sobretudo, na contabilidade das emprêsas e ação inteligente dos engenheiros. O critério que adotaram foi, portanto, do custo real, fortalecido pelo contrôle contábil e ação dos engenheiros.

No terceiro periodo prepondera a ação das comissões, que procuram melhorar cada vez mais o critério adotado, máxime após o discurso que, em 1930, Roosevelt pronunciou no banquete com que a Acádemia de Ciências Políticas encerrou as suas sessões dedicadas à discussão dos processos de contrôle dos serviços públicos concedidos. Durante essa época, as comissóes nunca deixaram de levar em conta o critério do custo histórico das propriedades. O aumento ou diminuição das tarifas constituía uma resultante do reajustamento do custo histórico à vista da mudança do valor do dólar. As variações das tarifas visavam fornecer um lucro estável aos investidores de capital e satisfazer o interêsse público.

O método que seguiam consistia em adaptar as tarifas às condiçóes econômicas ambientes, até chegar à odoção de uma base criteriosa e eqüitativa. Esse ponto de vista ainda hoje é adotado pelas comissōes. Difícil se torna,

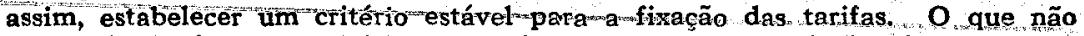
resta dúvida é que o critério preponderante entre as comissóes é o do custo histórico, aliado a outros fatôres vários. o que concorre para a existência de onze diferentes teorias nos Estados Unidos, segundo testemunho fidedigno de Frederick K. Beutel.

$O$ critério do custo histórico e custo de reprodução no Brasit - De modo geral, podemos dizer que o critério do custo histórico é o que considera, na avaliação para fixação de tarifas, reversão ou encampação de companhias, o custo original de tcdo o equipamento técnico, menos a depreciação. $\mathbf{E}$ o custo de reprodução é $n$ que considera de preferência o custo de instalação das emprêsas modificado pelas oscilações de preços do mercado.

O custo histótico e o custo de reprodução assumem denominaçao diversas ma terminologia corrente das utilidades públicas. Bilac Pinto classifica essas duas correntes em dois grupos : $10^{\circ}$ grupo : Historical cost - custo histórfo; Original cost - custo original ; Actual cost - custo real ; Prudent investment - inversão prudente. 2.0 grupo : Present fair value - justo valor atual ; Reproduction cost - custo de reprodução.

"Convém advertir. entretanto, prossegue o jurista brasileiro, que essas expressões não têm conteúdo uniforme na literatura especializada, e que muitas outras existem para significar critérios intermediários ou específicos, de avaliação". 2

Múltiplas são as controvérsias que se suscitam quanto a êsses dois critérios avaliativos. Demais disso, muitos são os que dizem que o critério do custo real se relaciona mais com o do custo de reprodução do que com b do custo histórico, porque actual também se traduz por atual, presente. No caso especial dos serviços de utilidade pública do Brasil, entretanto, de nada valem essas ciscussões sutis, já que o custo histórico é consagrado entre nós desde os tempos do Império.

Os adeptos do custo de reprodução se filiam à corrente individualista, rujos conceitos, embora predominantes até há bem poucos anos, vão grada-

2 BILAC PTNTo, Regulamentação efetiva dos serviços de utilidade pública, ed. Fevista Forense, Rio de Janeiro, 1941, pág. 204, nota 15. 
tivamente se substituindo por outros que apregoam a intervenção estatal na economia privada, como característica marcante do Estado moderno. Agrupam-se, assim, os adeptos do custo de reprodłução à ala dos economistas clássicos, que supõem seja o Estado incapaz de exercer o contrôle das atividades particulares. Também a essa escola se filiam as emprêsas que lutam por se subtrair à supervisão governamental e alguns contadores que não se assenhorearam ainda das verdadeiras finalidades dos órgãos encarregados da regulamentação dos serviços de utilidade pública, mantendo-se em manifesta posição conservadora.

No Brasil, aderem a esta corrente Lair Paleta de Resende Tostes e F. V. de Miranda Carvalho, ao passo que entre os que adotam o critério do custo histórico se contam Alfredo Valadão, Bilac Pinto, Temístocles Brandão Cavalcanti, Plínio A. Branco, Meirieles Teixeira, Luís Anhaia de Melo e Alves de Sousa.

Essa corrente advoga uma remuneração justa às emprêsas, e satisfaz plenamente aos interêsses dos usuários do serviço público.

A maioria dos tratadistas estadunidenses adotam o critério do custo histórico. Vemos, entre êles John Bauer, Martin Glaeser, Nash, William Mosher, Eliot Jones, Truman Bigham, Felix Frankfurter, Cassius Clay, John Maurice Clark, além de muitos outros, que seria ocioso enumerar.

Sustentou igualmente êsse critério Justice Brandeis no caso "Southwestern Bell Telephone". em 1923.

Entre os homens de govêrno que pugnam por uma democracia social, podemos mencionar Franklin Delano Roosevelt, que em seu livro Looking Forward patrocinou êsse critério avaliativo, imprimindo nova diretriz aos serviços de utilidade pública nos Estados Unidos.

O art. 180 de nosso Código de Águas consagrou inteligentemente o custo histórico como base de avaliação.

Consoante os ensinamentos de diversos tratadistas, podemos assim enumerar as principais vantagens do custo histórico: a) exprime o valor real da propriedade; $b$ ) garante a estabilidade financeira das emprêsas ; c) obriga os empresários a renovar constantemente o material; $d$ ) torna rápida a avaliação; e) os preços não sofrem oscilaçães.

Quanto ao custo de reprodução, nenhuma vantagem podemos apontar; antes, pelo contrário, inumeráveis são as desvantagens, cujas principais são as seguintes: u) as avaliaçōes são demcradas e acarretam grandes despesas; b) os resultados obtidos são incertos e vagos; c) traz lucros excessivos aos concessionários; (d) é nocivo aos interêsses dos usuários dos serviços de utilidade pública; d) é incompatível com a regulamentação efetiva.

Examinados perfunctòriamente êsses dois critérios, cabe-nos apontar os elementos que devem ser levados em conta na fixação razoável das tarifas.

O critério adotado pelo art. 180 de nosso Código de Águas, dada sua feição nìtidamente eqüitativa e judiciosa, pode-nos servir de base às futuras fixações de tarifas. Está assim enunciado:

"Art. 180. Quanto às tarifas razoáveis, alínea $b$, do art. 178, o serviço de águas fixará, trienalmente, as mesmas:

I - sôbre a soma do serviço pelo custo levando-se em conta :

a) tôdas as despesas de operações, impostos e taxas de qualquer natureza, lançados sôbre a emprêsa, excluídess as taxas de beneficio;

b) as reservas para a depreciação;

c) a remuneração do capital da emprêsa. 
II - tendo consideração no avaliar a propriedade, o custo histórico, isto é, o capital efetivamente gasto, menos a depreciação;

III - conferindo justa remuneração a êsse capital;

IV - vedando estabelecer distinção entre consumidores dentro da mesma classificação e nas mesmas condições de utilização do serviço;

V. - tendo em conta as despesas de custeio fixadas anualmente de modo semelhante."

Constitui êste, sem dúvida, o critério que melhor nos poderá servir de paradigma às futuras avaliações e conseqüente estabelecimento de tarifas.

Acresce, ainda, que, antes do Código de Águas, o art. 1. $\$$ 9., do Decreto n. 1.746 , de 1869 , já consagrava o custo histórico, o que demonstra ser êle da indole de nossas instituições administrativas:-

$O$ art. 147 da Constituição de novembro - Nos Estados Unidos, como vimos, sòmente através de lutas memoráveis é que se conseguiu legislação adequada à regulamentação dos serviços de utilidade pública. Na verdade, apenas depois de forte pressão do povo é que ali o Estado se viu na contingência de promulgar leis que, traçando normas à regulamentação, foram ao encontro dos anseios populares.

No Brasil, ao contrário, o aparecimento da fórmula jurídica indispensável ao contrôle dos serviços de utilidade pública deu-se de maneira diametralmente

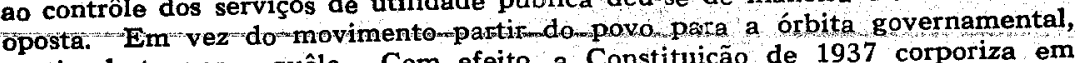
partiu desta para aquêle. Com efeito, a Constituição de 1937 corporiza em seu texto os elementos básicos à regulamentação de nossos serviços de utilidade pública, quando no art. 147 assim preceitua :

"A lei federal regulará a físcalização e revisão dos serviços explorados por concessão para que, no interêsse coletivo, delas retire - capital uma retribuição justa e adequada e sejam atendidas convenientemente as exigências de expansão e melhoramento dos serviços.

A lei se aplicará às concessõos feitas no regime anterior de tarifas contratualmente estipuladas por todo tempo de duração do contrato."

Entretanto, convém frisar que de nada valerá êsse dispositivo se perma necer, como até agora tem permanecido, letra morta no pacto constitucional. Na verdade, enquanto não se promulgar a lei orgânica federal a que atudo - art. 147, que deverá conter princípios fundamentais no concernente às utilidades públicas, jamais se poderá dar fiel cumprimento ao preceito legal. $\epsilon$, aliás, o pensamento que ressalta do n. 14 da declaração de princípios apresentada pelos Srs. Bilac Pinto, Anhaia de Melo, Alves de Sousa e Plínio A. Branco, à Comissão constituída pelo Sr. Francisco Campos, quando Ministro da Justiça, para fazer sugestões ao Govêrno Federal sôbre a regulamentação dos serviços de utilidade pública, que dêsse modo se ennucia:

"Será conveniente, entretanto, que a Lei Orgânica estabeleça alguns princípios cardeais, como sejam :

$I$ - concessão por prazo indeterminado;

II - regime de serviço pelo custo;

III - a base de tarifas deverá ser o custo histórico, isto é, o capital efetivamente gasto, menos a depreciação;

IV - na retribuição do capital, deve-se atender não apenas à natureza especial dos serviços, mas também à estrutura do capital do concessionário, a fim de que se não atribua ao capital-ações comuns uma retribuição incompatível com a natureza dos serviços." 
A Lei Orgn̂nica deverá especificar, pois, o critério mais acertado à fixação das tarifas, tarefa que caberá, sem dúvida, a um órgão especializado, por isso que dependerá de uma ponderação daqueles elementos a que 0 art. 180 do Código de Águas se refere.

Ao demais, releva ponderar que a fiscalizaccão e revisão dos serviços explorados por concessão, a que faz alusão o art. 147 da Constituição, sòmente se poderá fazer através de um órgão técnico, que conte com número regular de contadores, economistas, engenheiros e outros experts, e tenha amplas atribuições relativamente ao exame da contabilidade das emprêsas, a fim de possibilitar uma apreciação do capital invertido nas mesmas, a distribuição das açôes, o dividendo que cada acionista realmente recebe, ect., etc. Isto não acontece na regulamentação puramente contratual, cujos defeitos são evidentes, e que não enseja a que se faça uma fiscalizaçãa rigorosa-nas companhias; desde que, como é sabido, após a celebração do contrato de concessão quase nenhuma, ou nenhuma, é a função supervisora do Estado. Além disso, de que servé a lei outorgar poderes ao Estado para rever os contratos, já que êle não dispõe da maquinária necessária para saber se, em dado momento, deve, ou não deve, ser feita a revisão dos contratos?

Realmente, tanto a fiscalização dos serviços, como a revisão dos contratos a que se refere a Constituição de novembro, mais tarde fortalecida pelo decreto-lei n..$^{\circ}$.764, de 19 de agôsto de 1943, sòmente será realidade no dia em que se criarem comissões técnicas. Essa a razão primordial que nos induz a patrocinar a criação dessas entidades, como única medida capaz de regulamentar nossos serviços de utilidade pública. De resto, essa também é a opinião perfilhada pelo insigne jurista Temístocles Brandão Cavalcânti, ao assim expressar-se :

"Previu, támbém cutro diploma legal, o decreto-lei n." 5.764, de 19 de agôsto de 1943 , a revisão dos contratos e a possibilidade de modificações ali expressas, por ato unilateral da administração.

Vale a pena mencionar a amplitude dêsse decreto-lei, que compreende, embora tìmidamente, uma tentativa de estruturação legal de certas concessões.

Mas as normas ali consignadas serão inócuas se não se completarem por um sistema adequado de fiscalização nas execuções dos princípios ali mencionados.

Ficamos, assim, por enquanto, neste terreno-da- tímida-regulamentação dos contratos. Nẫo nos arriscamos ainda na delegação de todo o sistema de fiscalização a órgãos próprios, incumbidos de regulat tarifas e de solver as controvérsias porventura suscitadas na aplicação e interpretação dos contratos.

Esse objecivo, insistimos, só poderá ser atingido por um conjunto de medidas adequadas que encontraram em autros países a sua consagração legal na constituição de órgãos apropriados para disciplinar a vida das entidades que exploram os serviços de utilidade pública." 3

O dispositivo constitucional fala, outrossim, em retribuição justa e adequada do capital. Como podemos saber se o capital empregado nas emprêsas exploradoras de serviço de utilidade pública recebem uma retribuição justa e adequada?

E preciso, antes do mais, ter-se idéia clara da quantidade de capital empregado pelos acionistas nas companhias, o que só se obterá através de um exame rigoroso na escrituração das emprêsas, faculdade essa que a regulamentação puramente contratual não nos subministra. Além disso, os instrumentos de concessão não propiciam ao Estado os elementos necessários para que êle force as emprêsas concessionárias a expandir e melhorar os serviços, no caso de assim o exigirem as transformações técnicas e econômicas da so-

3 Temístocles B. Cavalcants, Tratado de Direito Administrativo, Livraria Freitas Bastos, 1944, vol. VI, págs. 51 e 52 . 
ciedade, induzindo-nos, à transgressão de mais uma parte do preceito constitucional.

Assim, tudo nos leva a crer que, para dar fiel e cabal cumprimento à disposição do diploma político de 1937 se faz mister a criação de órgãos autárquicos, de comissões como já existem nos Estados Unidos, onde, apesar de falhas a sanar, têm dado os melbores resultados.

A lei federal, de conformidade com o art. 147 da Constituição de novembro, terá efeito retroativo sôbre as concessốes feitas anteriormente a ela. Nem de outra forma poderia ser, já que as indústrias exploradas de serviços de utilidade pública não constituem indústrias de ritmo comum, mas, sim, indústrias que tém por objetivo precípuo a prestação. de serviços de tal ordem que impossível se tornaria deixá-las sujeitas ao livre jôgo dos interêsses privados. Com efeito, êstes não podem sobrepor-se aos lídimos interêsses da comunidade.

Das breves considerações que expendemos a respeito do art. 147 da Constituição, infere-se que, enquanto não se elaborar a Lei Orgânica Federal a que se faz alusão, e que conterá os princípios que já apontamos, bem como criará um órgão técnico aplicador dêles, jamais se poderá dar estrita satisfação oo estatuto constitucional.

Grandes dificuldades já foram superadas nesse sentido pelos membros encarregados da regulamentação do art. 147, e por isso já temos meio caminho andado. Basta prosseguir na tarefa, e teremos dado cumprimento ao que dispõe a Constituição.

As "Holding Companies" ou emprêsas vinculadas - Antes de entrarmos no exame da situação das emprêsas vinculadas em nosso país, convém expor de modo sucinto a posição que ocupam no vasto quadro econômico das sociedades comerciais.

$\mathrm{O}$ individualismo econômico predominante no século XIX engendrou a concentração capitalista em vários países da Europa, durante os últimos anos daquela centúria, do que a formação de poderosas sociedades anônimas, só por si, constituem prova irrecusável.

$\mathrm{Na}$ última década do século passado, paralelamente à instituição dos enormes monopólios capitalistas do Velho Mundo, também nos Estados Unidos surgiram gigantescas companhias, que centralizaram em suas mäos soma considerável de poderes econômicos, as holding companies, consideradas pelos economistas como instituição tìpicamente norte-americana. Essas sociedades se caracterizam, de um modo geral, por terem ações em outras companhias. São companhias acionistas de outras companhias. Vereis o que dizem sôbre

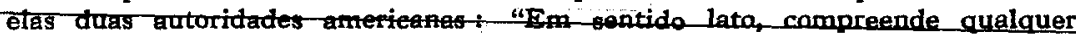
companhia que tem ações em outra companhia ou companhias." 4

Contudo, releva ponderar que a principal finalidade das holdings é fazer com que da interpenetração geral das emprêsas surja um contrôle eficaz e real.

O Companies Act de 1929 nos dá a seguinte definição das holding companies, mais ampla que a de Bonbright e Means : "Chama-se Holding Company aquela sociedade cujo ativo se compōe, no todo ou em parte, de ações de outra sociedade, sempre que o total dessas açóes ultrapasse $50 \%$ do capital emitido pela filial (subsidiary company), ou alcance logo tal montante que dê à sociedade proprietária das açōes mais $50 \%$ dos votos na sociedade filial, e é a Holding Company a sociedade que tem direito a nomear a maioria dos administradores de outras sociedades."

Quando pela primeira vez as holdings surgiram nos Estados Unidos, foi com o intuito de burlar as leis que proibiam o trust. Promulgou-se contra o trust o Sherman Act e o Clayton Act. Os capitalistas, em face dessa medida,

4 James C. Bonbright e Gardiner C. MEans, The holding company, Mc Graw Hill Book comp. Inc., New York and London, pág. 7 . 
que colidia com seus interêsses materiais, adotaram a holding como a forma jurídica mais adequada para salvaguardar seus interêsses. Adotaram êsse tipo de couraça a Standard Oil Company, U.S. Steel Corporation e a Illinois Steel Corporation. Nos serviços de utilidade pública, revestiram-se dessa modalidade de proteção legal a Bell Telephone Company em 1880, a United Gas Improvements Company, em 1888, depois das quais muitas outras se seguiram.

Atualmente, nos Estados Unidos, para manter as holdings sob o contrôle governamental, o Estado estabeleceu que era suficiente qualquer holding participar do Federal Reserve System, para que tôdas que com elas estivessem vinculadas também ficassem submetidas aos poderes de contrôle.

Em regra, no caso de organização piramidal, aliás predominante, essas campanhias estão constituidas por uma holding principal, situada no vértice da pirâmide, várias sub-holdingss, e as operating companies, as operadoras, na base da pirâmide.

Os managers, de que falaremos mais adiante, so bem que possuindo o menor capital das emprêsas, auferem os maiores lucros, e é contra êles que no caso especial do Brasil devemos dirigir nossa atenção. Êsses managers controlam o patrimônio das emprêsas operadoras.

$O$ professor W.Z.Ripley refere-se ao perigo das holdings, porque dão margem ao fácil enriquecimento dos managers, às expensas dos investidores das companhias subsidiárias. Há, pois, necessidade de analisar cuidadosamente a contabilidade das emprêsas, para que o capital seja retriburído justa e adequadamente.

Para têrmos uma noção clara do poder centralizado por êsses managers, vejamos o que dêles fala o Prof. Bilac Pinto :

"Para que o leitor possa avaliar, com aproximada exatidão a soma inimaginável de poderes enfeixados nas mãos dos managers das holding companies, que exploram serviços de utilidade pública, será preciso que se informe da literatura especializada, pois os problemas envolvidos são de tal maneira complexos que, em poucas linhas, não se pode dar; sequer, uma visualização parcial da sua magnitude"."

A administração das holdings é composta de dois grupos: diretores $\theta$ empregados principais. Os primeiros são eleitos pelos acionistas e exercem o cargo sem receber salários. Todavia, cabe-lhes a formulação das linhas gerais do programa politico das companhias. Nomeiam os empregados principais, que administram os negócios gerais das emprêsas de conformidade com a política geral prèviamente traçada pela- junta de diretores. Os diretores examinam periòdicamente os resultados da administração, aprovando ou desaprovando os atos praticados pelos empregados por êles nomeados.

O principal objetivo das holdings é, como dissemos, centralizar o contrôle das diversas emprêsas vinculadas. No caso especial da Bond and Share Company, que tem grandes ramificações pelo Brasil, podemos dizer que se situa no vértice da pirâmide, e controla as atividades das sub-holdings e das operadoras.

Essa centralização, porém, como fàcilmente se nota, produzirá as mais nefastas conseqüências, quando não sèriamente submetida à superintendência governamental. Essa a razão básica de os serviços de utilidade pública estarem sujeitos, nos Estados Unidos, ao contrôle estatal, e constitui mesmo setor da indústria privada onde mais forte se faz sentir o intervencionismo do Estado.

Hoje em dia, é tão importante o contrôle pelo Estado dos serviços de utilidade pública que A. Buehler, grande financista norte-americano, enumerando as funçōes gerais do Estado moderno, coloca a regulamentação dos serviços de utilidade pública em lugar de relêvo.

5 Bulac PnTro, Regulamentaçäo efetiva dos serviços de utilidade pública, ed. Rovista Forense, Rio de Janeiro, 1941, págs. 21 e 22. 
O caso das holdings ou emprêsas vinculadas, no Brasil, dificulta sobremodo a reunião dos elementos necessários à fixação de tarifas, reversão ou encampação das emprêsas, já que seus acionistas aqui não residem.

Dificuldades da avaliação em caso de emprêsas vinculadas - As emprêsas interconectadas, dado o caráter específico de que se revestem, apresentam maiores dificuldades para avaliarção, sobretudo no Brasil, em que os acionistas pertencem a outras companhias além das aqui existentes e residem fora do território nacional.

O caso típico das emprêsas vinculadas, como já vimos, são as holdings companies. Quanto às emprêsas não vinculadas, há apenas duas classes de interessados; os acionistas e os usuários, e a regulamentação, portanto, não oferece tantas dificuldades, porque menor é seu âmbito econômico. Constituem elas, no Brasil, a pequena indústria dos serviços de utilidado pública, e por isso, na sua regulamentação, o Estado deve exercer de preferência uma função assistencial, fomentando a expansão e melhoria de seu equipamento técnico, para que haja serviço adequado.

No Brasil, quiçá em tôda a América Latina, os principais serviços de utilidade pública estão centralizados em mãos de uma única holding company americana, a Electric Bond and Share Company. Se não, vejamos a opinião autorizada de Carl Brinkmann :

"The intluence of finance and holding companies are organized for foreign countries by electrical manufacturers to create and control markets for their equipment. Electricity supply in Latin America is dominated by the American and Foreign Power Company, which also has important interests in India, China and Europe. It is a subsidiary of the Electric Bond and Share Company and in 1929 . it had assets of $\$ 756,000,000$ ",,

Não obstante o autor acima mencionado falar sómente nos serviços de eletricidade como sendo explorados pela Bond and Share Company, podemos acrescentar, pelo menos quanto ao Brasil, que os serviços de gás e telefone também pertencem àquela emprêsa.

As holding companies que exploram serviços de utilidade pública podemse dividir, em regra, em dois grupos de interessados : a) inversionistas; b) managers.

Os primeiros representam quase todo o capital das emprêsas. Não exercem, porém, o contrôle, nem tampouco auferem lucros fabulosos. Contentam-se ccm pequenas rendas. $O$ contrário acontece com os managers, possuidores de ações comuns. Embora possuindo pequena parcela de capital, são êles os mais interessados na cobrança de tarifas elevadas e lucros exorbitantes.

Sôbre o mecanismo da dístribuição de lucros das holdings, citemos um exemplo de Julius Cohen :

"Vamos entrar agora com o preço de reprodução em uma holding company. Esse capital é muito pequeno, vamos supor $\$ 50.000 .000$.

\section{Títulos}

Obrigações . . ........

Ações preferenciais .......

Ações comuns ..........
Capital

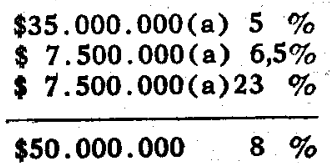

Lucros

$\$ 1.750 .000$

$\$ 487.500$

$\$ 1.762 .500$

$\$ 4.000 .000$

Os acionistas recebem dividendos de $23 \%$, embora se tenha atribuído - lucro razoável de $8 \%$.

6 CARL BRINKMann, Pablic Utilities, em Encyclopaedia of the Social Sciences, New York, The Macmillan Company, 1937, vol. 12, pág. 676. 
Entra o custo de reprodução agora, valor dcbrado, um caso comum antes da depressão.

Retribuição de $8 \%$ sôbre $\$ 100.000 .000$, correspondent.è a $\$ 8.000 .000$.

Teremos, então :

Titulos

Capital

$\$ 35.000 .000$ (a) $5 \%$

$\$ 7.500 .000$ (a) $6.5 \%$

$\$ 7.500 .000$ (a) $76 \%$
Lucras

$\$ 1.750 .000$

$\$ 487.500$

$\$ 5.762 .500$

Açôes comuns

Os acionistas comuns estão recebendo $76 \%$ de dividendo anual.

Este lucro é fabuloso; está, realmente, a pedir uma holding company para capitalizá-lo :

A holding compra as ações comuns, obrigaçōes a $5 \%$, e $\$ 2.000 .000$ de ações preferenciais a $6 \%$, que vende ao público; e $\$ 1.500 .000$ de ações comuns, que guarda em carteira.

Quais serão os lucros das holdings?

\section{Titulos}

Obrigações (holding) ...

Ações preferenciais (idern)

Juros das obrigaçōes e ações preferenciais da subsidiária . . .......

Ações comuns (holding).

\section{Capital}

$\$ 4.000 .000$ (a

$\$ 2.000 .000$ (a

$5 \%$ )

$6 \%$ )

$\$ 1.500 .000$ (a 362\%)

$\$ 7.500 .000$
Lucros

$\$ 200.000$

$\$ 120.000$

$\$ 2.237 .500$

$\$ 5.442 .500$

$\$ 8.000 .000$

$362 \%$, eis o dividendo das ações comuns da holding. "Parece fantasia diz Mosher - mas está perfeitamente dentro da realidade dos fatos".7

Diante dêsses dados, o leitor pode aquilatar, mais ou menos, a situação dos inversionistas, dos managers e dos usuários, bem como os maléficos efeitos que às sociedades pode trazer o critério avaliativo do custo de reprodução. Dai porque os managers preferem o critério do justo valor atual ou custo de reprodução, que thes proporciona lucros fabulosos.

As tarifas como fator de ordem pública - As tarifas, quando fixadas no instrumento contratual, em que prepondera a vontade do concessionário, não se podem revestir do caráter público exigido pela lei. Isso porque, uma vez firmado o contrato de concessão, o Estado perde o contrôle sôbre elas, que são fixadas por todo tempo de duração do contrato. Nem de outra forma poderia acontecer numa época em que a intervenção do Estado na esfera privada apenas se fazia sentir de maneira tíbia e irresoluta.

Nos dias que correm, entretanto, em face das crescentes necessidades sociais, o poder de polícia do Estado ampliou-se de maneira surpreendente, mormente no setor da economia privada, acarretando, por seu turno, profundas transformações no conceito de serviço público.

Léon Duguit, profundo jurista francês, já assinalava que no contrato de concessão há duas espécies de cláusulas, as regulamentares e ás contratuais. Eis as palavras proferidas pelo insigne mestre:

"Sont clauses contractuelles toutes les dispositions que ne seraient pas concevables si le service public était exploité en régie, comme par exemple.

7 Julrus CokEN, apud Lufs DE ANHAta Melo, $O$ problema económico dos serviços de utilidade pública, São Paulo, pub. da Prefeitura do Município de São Paulo, 1940, pág. 238 ,

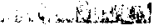


celles relatives à la garantie d'intérêt, aux subventions payées par l'administration, au partage des bénéfices, aux redevances payées par le concessionaire. Au contraire, sont clauses réglementaires formant véritablement la loi du service celles que contiennent des dispositions concevables et existant en fait pour un service public exploi directement par l'administration, par exemples les dispositions relatives au mode d'exploitation, au nombre et à la vitesse des trains s'il sagit des chemins de fer concedé, aux tarits, aux conditions de securité, aux salaires des employés." 8

Por êsse tópico se vê que a questão referente às tarifas se coloca entro as situações regulamentares do contrato, e, uma vez sendo, cabe sem dúvida ao Estado intervir constantemente na fixação das mesmas, alterando-as e adaptando-as a cada caso particular, se assim o exigir a eficiência do serviço público, mesmo que êsse direito não the seja reconhecido no instrumento contratual.

Essa é a doutrina corrente a respeito de tal assunto. Leiamos a propósito a opinião de A. Gonçalves de Oliveira, Consultor Jurídico do Ministério da Viação e Obras Públicas :

"Todos os autores, nacionais e estrangeiros, estão acordes em que há, em tôda concessão, a par da situação contratual, situações regulamentares, que facultam ao poder concedente o direito de intervenção, de fiscalização, de contrôle e direção do serviço concedido. O serviço, apesar da concessão, não perde o seu caráter de serviço público e, por isso mesmo, o poder concedente tem o direito de organizá-lo eficientemente, realizando tôdas as modificaçóes necessárias para o seu bom funcionamento, ainda quando êsse direito não esteja expresso no contrato"'.9

Atualmente, é doutrina assente que a fixação tarifária deve emanar do poder discricionário do Estado e não do direito subjetivo do concessionário, embora seja êste prèviamente ouvido. Quase todos os autores norte-americanos ensinam que o poder de estabelecer e regular tarifas se considera atribuição inerente ao poder de polícia do Estado, fato êsse de que o número considerável de comissões estaduais e municipais existentes nos Estados Unidos constitui prova irretorquível.

Esse poder do Estado fundamenta-se em que o serviço prestado pelos concessionários, dado seu caráter visceralmente público, é como se fôra diretamente prestado pelo Estado concedente. O particular sub-roga-se na função do Estado, subtraindo-lhe parte da soberania $O$ objetivo, pois, das emprêsas particulares, não deve consistir apenas no lucro, mas, sim, na ampla prestação do serviço público, razão por que a intervenção do Estado nesse setor da atividade particular constitui, modernamente, ponto incontroverso.

E diga-se mais : fixar, rever e homologar tarifas constitui não um poder do Estado, mas um dever que se the impóe, porque vivemos a fase do Estado de direito, de que já tanto se ufanava Otto Mayer relativamente a seu país natal.

Segundo Rafael Bielsa, as tarifas devem obedecer às regras que êle assim enumera :

"1. El precio del servicio no debe exceder del total formado por el costo e el interés normal de explotación. Para ello es necesario que haya certeza en los informes de la explatación y de la "cuenta capital". Toda reticencia o dolo del concesionario a este respecto debe ser causa de caducidad;

8 Lfon Duguir, Droit Constitutionnel, tomo I, pág. 314.

9 A. Gonçalves De Olrvetra, parecer inzerto na Revista do Serviço Puiblico, fevereiro de 1945, pág. 91. 
2. La Administración pública concedente debe rever la tarifa periódicamento o cuando las circunstancias especiales lo exijan, de acuerdo con las bases de la concesión. En esto la administración pública tiene un poder necesario e virtual;

3.' Ninguna tarifa puede ser aplicada si previamente no ha sido autorizada u homologada según la ley. El concesionario no puede aplicar moto proprio una tarifa". 10

Essa última parte evidencia claramente que a vontade do concessionário na aplicabilidade das tarifas deve subordinar-se ao ditames da lei. Na verdade, seria inconcebível que no caso, a lei fôsse aplicada em regime idêntico ao do setor das indústrias comuns, onde a liberdade econômica engendra as variações constantes dos preços das mercadorias.

Concluímos, pois, que o interêsse público é o preponderante, porque, embora os servicos de utilidade pública estejam organizados-em-forma-de-emprêsa privada, devem ser controlados pelo poder estatal, dada a função eminentemente social de que se revestem.

Sôbre êsse aspecto do problema, ouçamos as palavras incisivas e convincentes do jurista argentino Emilio L. González, que esclarecem definitivamente a posição das tarifas como elemento jurídico regido pelo direito público :

"La tarifa, como interés jurídico que merece protección, no es un derecho privado que se origine en la propia voluntad privada, como un objeto del derecho privado. La tarifa, como elemento complementario de una concesión de servicio público, es un elemento jurídico regido por el derecho público, institứdo en beneficio del interés de la colectividad y también del concesionatio.

De esta esencial caracteristica que hace que la tarifa tenga su origen en las disposiciones de derecho administrativo, que gobiernan e instituyen los servicios públicos, resulta evidente que ella existe y prolonga su existencia juridica, de conformidad a las disposiciones legales o doctrinarias que autorizan sua vigencia". 11

Considerações finais - Já John Bauer acentuava avisadamente que a regulamentação das utilidades públicas é função essencialmente legislativa. Efetivamente assim acontece. $O$ Estado sòmente intervém na vida privada quando a legislação the permite exercer atividade de tal gênero, pois que está sujeito às regras jurídicas de direito público. $E$, como vimos atrás, a regulamentação dos serviços de utilidade pública implica, antes de mais nada, a faculdade outorgada ao Estado para intervir no setor das utilidades públicas.

No Brasil, desde que até agora, em virtude de múltiplos fatôres, não se deu real cumprimento ao art. 147 da Constituição, cujo primeiro passo consistiria na elaboração da Lei Orgânica Federal, não podemos falar em efetiva regulamentação de nossos serviços de utilidade pública, já que tal medida só se concretizará através da instituição de entidades autárquicas.

Continuamos, assim, no regime da regulamentação puramente contratual de nossos serviços de utilidade pública, contra o qual se insurgem nossas mais altas autoridades em direito administrativo, que, apontando seus inúmeros defeitos, propugnam pela criação de órgãos técnicos como medida mais salutar para a solução do caso.

Permitem que ajuizemos perfeitamente da regulamentação puramente contratual e de seus efeitos deletérios as seguintes palavras do Prof. Fran-

10 Rafazl BiElsa, Derecho Administrativo, 3,a ed., J. Lajouane \&s Cia., Buenos Aires, págs. $343 \bullet 344$.

11 Emilo L. González, Contralor y rescate gubernatiro de los servicios públicos, Buenon Aires, 1938, pág. 30. 
cisco Campos, que pöem ponto final na questão: "O único processo, de que até aqui usamos para controlar os serviços públicos concedidos, é o contrato. Por êste processo, os deveres e os direitos do concessionário são fixados de uma vez por tôdas e para um longo período no próprio instrumento da concessão. Os concessionários não tếm, na generalidade dos casos, nenhuma obrigação de introduzir nas instalações e nos serviços as conquistas, dia a dia crescentes, da tecnologia do ramo de indústria que exploram. A tarifa é fixada para tôda a duraçâo do contrato. $O$ contrato constitui, assim, para o con-
cessionário, uma armadura inexpugnável, que o coloca quase totalmente a coberto de qualquer ingerência do Estado nos seus negócios. Uma vez fixadas no contrato as condições, o negócio passa a ser, não um negócio público, como devera, mas um negócio particular, em que o público representa apenas uma clientela despersonalizada e incapaz de organizar-se para fazer valer os seus interêsses, definidos, de uma vez por tôdas, pelo instrumento contratual, embora venham a variar as condiçôes técnicas e econômicas próprias ao serviço. Por êsse processo antiquado e obsoleto de contrôle, que tem por fim reduzir o Estado apenas à fase pré-contratual, uma vez que, na contratual, reduzido a quase nada é o território da sua tutela, inspeção ou vigilância, resume-se ao mínimo indispensável o elemento público no serviço, ampliando-se, ao contrário, a área do elemento particular, representado pelos capitais invertidos no serviço". 12

A promulgação da esperada Lei Orgânica Federal seria, sem dúvida, fator decisivo para a criação das comissōes, já que daria amplas possibilidades ao Estado para intervir no setor das atividades públicas, ministrando, assim, ao planejamento econômico, nessa área da iniciativa privada, base sólida, indis. pensável à eliminação dos prejuizos-sosiai su decorrentes do liberalismo econômico, com ajustar a produção das utilidades às reais necessidades de consumo.

De resto, é sabido que o desenvolvimento intensivo das fôrças produtivas clama por uma demarcação nítida entre os interêsses públicos e privados, a fim de permitir um justo planejamento para o futuro e um tratamento adequado aos investidores de capitais. E para isso a adoção de uma política clara e definida terá de se basear, por certo, num seguro critério avaliativo para fixação de tarifas justas e razoáveis.

Acresce que, uma vez que o govêrno brasileiro, há bem pouco tempo, instituiu o Conselho Nacional de Política Comercial e Industrial, no Ministério do Trabalho, Indústria e Comércio, e a Comissão de Planejamento Econômico, subordinada ao Conselho de Segurança Nacional, tudo leva a crer que pretende afastar-se dos princípios da economia clássica, preparando, assim, a vida nacional para arrostar com os árduos problemas que surgirao após a conftagraçáa mundial que se avizinha de seu fim.

Destarte, desde que se presuma seja atribuído ao Conselho Nacional de Politica Comercial e Industrial a parte referente ao planejamento das atividades privadas, seria de conveniência, para sua maior unidade orgânica, fôsse criađa quanto antes uma comissão federal, que se encarregaria não só da regulamentação, mas também do planejamento de todos nossos serviços de utilidade pública.

Essa comissăo federal, antes de enviar a programação de seus trabalhos ao Conselho Nacional de Política Comercial e Industrial, receberia os planos parciais das subcomissóes estaduais, imprimindo, assim, uniformidade substancial ao planejamento geral das utilidades públicas.

Dessa maneira, podemos afirmar, de antemão, que, enquanto não se elaborar a Lei Orgânica Federal, regulamentadora do art. 147 da Constituição,

12 Francisco Campos, Direito Administrativo, Imprensa Nacional, Rio de Janeiro, 1943, págs. 130 - 131 . 
dentro nos moldes já apresentados, impossível será regulamentar efetivamente nossos serviços de utilidade pública. Ademais, será dificil ao Conselho Nacional de Politica Comercial e Industrial dar cabal cumprimento às suas atribuições de órgão planejador das atividades privadas, sem que antes se alicerce no planejamento das utilidades públicas a ser feito pelas comissões. Isso não só constituirá uma irrealidade como dificultará a execução do programa atribuído à Comissão de Planejamento Econômico, desde que se presuma o Conselho Nacional de Política Comercial e Industrial esteja subordinado àquela Comissão.

Eis mais um motivo ponderável que nos leva a apadrinhar a criação de uma comissāo federal e tantas sub-comissōes quantas são as unidades federativas do Brasil, o que não só dará margem à regulamentação efetiva de nossos serviços de utilidade pública, mas também servirá de fundamento para imprimir unidade orgânica ao planejamento das atividades econômicas nacionais.

O primeiro passo para isso seria a promulgaçâo da Lei Orgânica Federad, medida que, aliás, em nada mais consistiria senão no fiel cumprimento dó dispositivo constitucional, que até agora continua inoperante, aguardando execução. 